\title{
$11 *$ Gendering Abortion Debates: State Feminism in Spain
}

\author{
Celia Valiente
}

\section{$\because$ INTROdUction}

There has been punishment for abortion in Spain since medieval times. With the first penal code in 1822, the state punished those performing abortions with prison terms, and subsequent legal reforms changed this criminalization only slightly until the 1980 os. However, there is a precedent for reform that dates back to the 1930 s when, during the civil war of 1936-9, a decree in Catalonia permitted abortion on grounds of the woman's health when she did not want the pregnancy and when the child would have physical defects. Given the upheaval that ensued, the reform was implemented in a very limited way (Nash 1986: 227-38).

From the mid-1930s to 1975 , Spain was governed by a right-wing authoritarian regime that actively opposed the advancement of women's rights and status. On 24 January 1941, voluntary abortion was again defined as a crime. In 1944, this anti-abortion act was repealed, but the articles related to abortion were included in the Penal Code. The 1944 Penal Code punished abortion with prison for between six months and six years. Abortion was a crime with no extenuating circumstances for the woman, unless she became pregnant while unmarried and subsequently had an abortion (Barreiro 1998: 35).

A partial decriminalization of abortion took place in 1985 . Since then, abortion has been a crime punishable by the Penal Code except on three grounds: when the woman has been raped-so-called 'ethical abortion'; when pregnancy seriously endangers the physical and mental health of the motherso-called 'therapeutic abortion'; and when the foetus is deformed-so-called 'eugenic abortion'.

Most groups in the Spanish feminist movement have been united in calling for abortion on demand since the 1970s, when Spanish feminists first mobilized 
in favour of decriminalizing abortion (Sundman 1999; Trujillo 1999). The main women's policy machinery at the central state level, the Women's Institute (Instituto de la Mujer), established by the socialist government in 1983, managed to influence the debate prior to the regulations of the implementation of the 1985 decriminalization of abortion, facilitating women's access to abortion services.

Unlike in the United States, Germany, or Ireland, the abortion issue no longer provokes intense conflict in the policy-making process. Although feminists continue to advocate abortion on demand, and some pro-life groups are active, the political controversy on abortion has been deactivated since the late 1980s. The Catholic Church does not agree with some acts of the Spanish state on moral matters, such as the act that legalized divorce in 1981 or the one that partially liberalized abortion, but it has not made a big effort to reverse them. Catholics' resistance to these public policies has been more moderate in Spain than in other Western countries (Linz 1993: 44).

\section{* Selection of Debates}

The period of study for this chapter is post-authoritarian Spain, from 1975 to the present. Two institutions dominate the policy area regarding the termination of pregnancy at the central state level: Parliament and the government, composed of the prime minister, the cabinet, and ministries. Acts of Parliament set forth the general legal framework while the ministries-in the case of abortion, the health ministry-establish regulations to implement the law. Royal decrees, enacted by the government, are the highest-ranking regulations emanating from national government departments (Newton and Donaghy 1997: 66). These institutions are the arenas in which major debates over abortion take place.

Parliament is composed of two chambers: a lower chamber called the Congress of Deputies, and an upper chamber called the Senate. In practice, although not in constitutional theory, the former is much more important than the latter, and the Congress of Deputies has precedence over the Senate in most matters. Members of the Congress of Deputies are elected by proportional representation under the D'Hondt system with closed and blocked lists. The province serves as the constituency. The vast majority of senators are elected by a majority system. The province is again the constituency, and each province elects four senators, although each voter casts votes for only three senators. The remaining senators are elected from among the members of regional parliaments according to the population of the regions and the political composition of regional parliaments.

Parliament functions in both plenary sessions and committees. Most parliamentary work takes place in committees, the majority of which are legislative

$\because$ Celia Valiente 
standing committees. Different units have the power to initiate legislation: government, Congress of Deputies, Senate, and regional parliaments. However, in post-authoritarian Spain the constitution set up a political system which includes a strong executive and a weak parliament, so that most laws have been initiated by government. The dominance of the executive is further strengthened by the dominance of political parties. There are strict controls on individual MPs. For instance, only parliamentary groups-in general composed of deputies and senators from a party or coalition-are allowed to introduce legislation. During 1982-93 the socialist party had an absolute majority in the parliament, and the independence of the parliament and opposition MPs declined even further (Heywood 1995: 99-101; Newton and Donaghy 1997: $45-72)$.

The universe of policy debates on abortion in Spain is small, especially in comparison with other countries in Europe and North America. For one thing, the democratic period when such debates came to the agenda began only in the late 1970s. In addition, the dominance of the parties in government-first the socialists and then a centre-right coalition-have left little policy space for either advocates or opponents of liberalized abortion. That abortion was a potentially extremely divisive issue was apparent early in the formation of the democratic state. During the process of drafting the constitution, between 1977 and 1978 , abortion was an issue that, together with education, regionalism, and divorce, among others, divided the left and the right to such an extent that it threatened to derail the constitutional process. Given this conflict, the political parties agreed that the constitution would not explicitly say anything about abortion. Conflict was therefore avoided by postponing it.

The first important piece of legislation on abortion was the organic Act $9 / 1985$ of 5 July, on the reform of article 417 bis of the Penal Code-hereafter 'the 1985 abortion act'. The 1985 abortion act decriminalized ethical, therapeutic, and eugenic abortion. The 1985 act, however, does not say anything more concrete about the implementation of abortion with respect either to the conditions under which health personnel could refuse help in abortion cases for reasons of conscience, or to the characteristics of clinics where performance of abortion would be permitted (Barreiro 1998: 238). Therefore, regulations were necessary for the implementation of the 1985 act. The government prepared these regulations, which were adopted in 1986.

Since 1986, there have been several failed attempts by left-wing parties to reform the 1985 abortion act. Although they presented bills to parliament, the reformers knew that without a majority to approve them their efforts would be symbolic. Thus, there have been no subsequent changes to the 1985 abortion act.

Two debates have been selected to represent abortion policy making in postauthoritarian Spain. The first is the debate beginning in 1983 leading to the 1985 abortion act. This debate is central to the issue, but it does not provide an 
opportunity to examine state feminism because the women's policy agencythe Women's Institute-was in the process of being founded during the debate and had little chance to participate. The second important legal piece in the policy area under study here is the regulations of the implementation of the 1985 abortion act: Royal Decree 2,409/1986 of 21 November.

Given the small universe of abortion debates in Spain, two debates, rather than three as in the other chapters in this book, adequately represent the policymaking process on the issue. These debates fulfil the criterion of issue salience. According to scholarly secondary sources (Barreiro 1998; Marín 1996), the 1985 abortion act and its regulations are the main measures taken in post-authoritarian Spain in the policy area of termination of pregnancy. The criterion of decisional system importance is also satisfied since the main institutional site of the 1985 debate was Parliament, and that of the 1986 debate was the executive. Given that the government's attention to the abortion issue was concentrated in the 1980 s, selecting these important debates also, in effect, represents the narrow range of debates. ${ }^{1}$

\section{* Debate 1: Decriminalization of Ethical, Therapeutic, AND EUGENIC ABORTION, 1983-1985}

\section{* How the debate came to the public agenda}

Although the socialist party-Partido Socialista Obrero Español, PSOE—had not included references to abortion in its 1977 and 1979 electoral programmes, other party documents issued in the 1970s, such as the resolutions of federal congresses, advocated radical reforms, for example, abortions provided free of charge by the public health system. Nevertheless, the party was divided mainly between supporters of a broad abortion liberalization and supporters of a more limited reform. In the context of electoral competition, PSOE leaders took the latter position. This was part of their overall strategy to convert the PSOE into a moderate catch-all party capable of achieving power (Barreiro 1998: 172-7).

In order to fulfil a compromise included in its 1982 electoral programme, the socialist government presented a bill on the reform of the Penal Code on $25 \mathrm{Feb}-$ ruary 1983. The bill contained an article that decriminalized abortion on ethical, therapeutic, and eugenic grounds (Barreiro 1998: 183-4). This parliamentary debate began six years after the first democratic elections were held in Spain, and four months after the PSOE first came to power, which it retained until Spring 1996. The debate started eight months before the Women's Institute was established. 


\section{- Dominant frame of the debate}

The dominant frame of the debate was composed of two types of arguments. Supporters of the decriminalization of abortion argued that, since abortions would be performed no matter what the laws said, it was reasonable to adapt the law to this social reality. They maintained that this reform would make Spain more like other European countries, which were economically more developed and had a longer democratic past. On the other hand, pro-life MPs often couched their support for the criminalization of abortion in terms of the defence of the fetus's rights.

The PSOE defended its reform bill in the Congress of Deputies arguing, among other things, that the reform was constitutional and that according to opinion polls it was supported by the majority of the population. ${ }^{2}$ Socialist leaders emphasized the moderate character of the bill, pointing out that, apart from three exceptions, abortion would still be a crime punishable under the penal law. Only the communist party advocated abortion on demand in the first three months of pregnancy performed free of charge in public hospitals.

Among the chief opponents of the bill was the main political party in opposition, the conservative Alianza Popular (AP). Most, although not all, AP deputies were against any sort of decriminalization of abortion. Members of the centre-right Unión de Centro Democrático and the Basque Nationalist Party (Partido Nacionalista Vasco), parties with fewer seats than AP, also took a prolife position. A division of opinion characterized-and still does-the Catalan nationalist coalition (Convergència $\mathrm{i}$ Unió). MPs from the Christian Democratic Unió opposed abortion. While some MPs from Convergència were pro-life, many others were pro-reform and liberalization. The main arguments of the opponents of the decriminalization of abortion were, among others, that the bill was unconstitutional and that abortion is murder, because, according to them, life starts at the moment of conception. In the Senate, arguments for and against the bill were similar to those advanced in the Congress of Deputies. ${ }^{3}$ Amendments from the opposition of similar content were also defended and defeated (Barreiro 1998: 217-9).

\section{* Gendering The Debate}

On the whole, the debate was not gendered, with a few exceptions. At times MPs supporting reform described women as people with the right to choose whether or not to continue an unwanted pregnancy. Members of the communist party-but not of the socialist party-sometimes used the argument made by the feminist movement that women had the right to freely dispose of their own bodies. Otherwise, references to the constitution, the foetus, doctors, and public opinion far outnumbered references to women. 
When MPs who supported liberalization explicitly referred to women, they tended to talk in the context of social class. Socialist and communist MPs denounced the fact that rich women could afford a safe abortion performed abroad while poor women had to suffer unsafe clandestine abortions at home, calling it a socio-economic injustice. In fact, they tended to be more concerned with class inequalities than with gender differences. They portrayed women as weak people experiencing anxiety, insecurity, and distress before abortion. They asserted that women opt to have an abortion only in very extreme circumstances: otherwise, all women really want to give birth to their babies because nobody would want to have an abortion. To them, it seemed as if women were forced by disturbing and unbearable circumstances to get rid of their pregnancies. Women were never presented as serene people who in ordinary circumstances would rationally opt for an abortion as their first choice. These ordinary circumstances seemed not to exist. ${ }^{4}$

Pro-life MPs mentioned women only in terms of their anatomy, specifically their wombs. A pregnant woman was, in effect, two people because the fetus in a woman's womb was independent from the moment of conception. Sometimes, pro-life MPs portrayed Spanish women as ignorant of contraceptive devices or unable to have access to them. Thus, unwanted pregnancies were likely. So, if the act were passed, women would try to cheat on the law in order to have abortions on grounds not permitted by the law. Pro-life, but not prochoice, MPs also talked about men as fathers, demanding fathers' consent in abortion cases.

\section{* Policy outcome}

Since the PSOE had an absolute majority in Parliament, the abortion reform bill was approved in the Congress of Deputies and sent to the Senate. On 30 October 1983, the Senate approved the bill. Two days after this approval, but before the bill was enacted, conservative MP José María Ruiz Gallardón, supported by 54 MPs, lodged an appeal before the Constitutional Court (CC) on the ground that the bill was unconstitutional. The $\mathrm{CC}$ has a responsibility equivalent to that of the Supreme Court in the United States, that is, to be the supreme interpreter of constitutionality', and can rule that laws are unconstitutional and invalid. It reviews laws made by the Spanish Parliament, the national executive, and regional governments, and its decisions apply to the whole territory of Spain and cannot be appealed (Heywood 1995: 105-6). The abortion reform policymaking process was stopped until the CC pronounced its sentence (Barreiro 1998: 219-20).

It took a year and a half, but on 11 April 1985, the CC made public its decision. The Court declared that the bill would be constitutional provided that it was modified to require that abortions be performed in authorized private or public

\section{* Celia Valiente}


centres. The Court went on to require a medical report certifying the grounds of the abortion prior to the procedure in the case of therapeutic and eugenic abortion, in order to provide more protection for the fetus (Barreiro 1998: 219-27, 231).

After the CC ruling, the socialist government revised the bill in accordance with the $\mathrm{CC}$ recommendations and again submitted it to Parliament. The debates in the Congress of Deputies and the Senate wereless virulent than before the publication of the CC sentence. ${ }^{5}$ The reason is that, around this time, the conservative party changed its position. If before 1986 the AP had frontally opposed any attempt to decriminalize abortion, it softened this opposition afterwards. After deliberation and approval in Parliament, the abortion act was enacted on 5 July 1985; it decriminalized abortion on grounds of the physical and mental health of the mother, the deformity of the fetus, and pregnancy due to rape.

\section{* Movement impact}

Representatives of the women's movement did not directly participate in the parliamentary debate that preceded the 1985 abortion act. The movement did mobilize, demanding decriminalization of abortion and organized pro-choice street demonstrations. Some members of the parliamentarian elite noted their activities, and a few times pro-choice MPs referred to the women's movement as a collective actor outside parliament that denounced gender inequalities and mobilized to remedy them. These references to the women's movement were complimentary. ${ }^{6}$ However, the overwhelming majority of the numerous participants in the debate were men. A male deputy from the Mixed Parliamentary Group Bandrés Molet publicly noted and denounced the lack of women's voices. Only three female MPs participated in the very long debate: deputy Pelayo Duque, Senator Ruiz-Tagles Morales, and Senator Sauquillo Pérez del Arco. All were pro-choice.

The policy content of the 1985 abortion act coincides with women's movement goals but only to a certain extent. An overwhelming majority of groups in the women's movement supported the decriminalization of ethical, therapeutic, and eugenic abortion. However, most feminist groups also supported and mobilized for a further decriminalization of abortion, that is, abortion on demand. Thus, with a liberalized abortion law, but not admitting women or movement groups to the policy process during this important debate, the state's response to the women's movement was one of pre-emption.

* Women's policy agency activities

The Women's Institute (WI) was officially created in 1983 (Act 16 of 24 October). It took almost two years from its foundation to hire the whole staff and to establish the directive organs. Therefore, the establishment of the WI partly 
coincided with the debate that preceded the 1985 abortion act. The scope of the WI is very broad, since the WI has five comprehensive goals: to promote policy initiatives for women through formal enactment of policy statements; to study all aspects of women's situation in Spain; to oversee the implementation of women's policy; to receive and handle women's discrimination complaints; and to increase women's knowledge of their rights. The WI was a permanent bureaucratic agency and not a political appointment. Since the WI was in a ministry rather than having a cabinet position, it has always been distant from major power centres. Up to 1988 the WI was a part of the Ministry of Culture and between 1988 and 1996 a part of the Ministry of Social Affairs. These ministries are two of the least important in the Spanish state. ${ }^{7}$ In the mid-1980s, the WI had not yet acquired an extensive staff and budget.

The leadership of the WI between 1983 and 1988 had much to do with the agency's activities. The director in that period, Carlota Bustelo, revealed a good deal of knowledge and understanding of gender inequality. She could identify openings of policy windows to push for reforms. She often gave the personal impression of having power and was likely to be obeyed. She made a number of initiatives and promoted demands on many fronts: education, labour market, reproductive rights, and so on. For allies, she chose former members of the women's movement. Bustelo was a well-known former PSOE deputy and feminist activist. Abortion was one of the top priorities of the WI in the mid-1980s. ${ }^{8}$

During the early period of the debate under study here, the Women's Institute did not exist and, in the later stages, formally existed but was still in the process of formation. Thus the WI had very few chances to participate in the debate. In line with the concerns of the women's movement, however, the WI did put pressure on the PSOE government to take the lead on the abortion reform question. After the decision by the Constitutional Court, WI director Bustelo urged the government to move more rapidly to solve what she termed the grave problem that the criminalization of abortion caused for many women (Barreiro 1998: 228). Thus, by adopting a position on the issue allied with the women's movement but being unable to gender the dominant frame of the abortion debate, women's policy agency activities were marginal.

\section{$\because$ Women's movement characteristics}

After emerging in the 1960 s and early 1970 , and growing from 1975 to the early 198 os, by 1983-5 the women's movement was in a stage of consolidation (Rosenfeld and Ward 1996). ${ }^{9}$ Nevertheless, the Spanish feminist movement, while not negligible, has been historically weak, its activities involving only a minority of women. The movement has occasionally shown some signs of strength, however. For example, it has organized national feminist conferences regularly attended by between 3,000 and 5,000 women. Nevertheless, in comparison with other 
Western countries, the movement in Spain has not achieved high visibility in the mass media or initiated many public debates. In the 1980s, most of the feminist groups were very close to the left, and abortion was a priority for the women's movement. The Catholic Church was the main pressure group against the decriminalization of abortion and led a strong counter-movement to reform. Recognizing this, the PSOE moderated its position on abortion before the 1982 election in order to attract Catholic voters and avoid a frontal clash with the church. Once in government, the PSOE went on to seek legal abortion but only on limited ethical, therapeutic, and eugenic grounds (Barreiro 1998: 19,189).

\section{* Policy environment}

The debate under study took place in Parliament, which has some characteristics of closed policy environments: parliamentary proceedings are codified through regular meetings and rules, and participation is limited to leaders of political parties with parliamentary representation. However, it would be an over-statement to say that one major actor-the PSOE—controlled the policy space and parameters of the arena. Theoretically, parties other than the PSOE could affect the content of the bill through amendments. Practically, this was very unlikely, because the PSOE had an absolute majority in Parliament and could use it to block any amendment. But the system was opened a little because opposition parties could appeal to the CC. Since the beginning of the parliamentary debate, the conservative Alianza Popular declared that it would appeal to the CC, which it in fact did.

On other hand, as mentioned, at the time of debate prior to the 1985 abortion act the party in office was the socialist party, which had the absolute majority of seats in both chambers. Generally speaking, left-wing parties are considered to be more receptive to social movements than conservative parties, and in this case the left-wing party arrived in office with abortion reform on its agenda.

\section{* Debate 2: The Regulations of the 1985 Abortion Act, 1986 \\ * How the debate came to the public agenda}

The rules involving of the implementation of the abortion legislation are very important, because they determine whether access to abortion services is easy or difficult for women. As Joyce Outshoorn (1996b: 150) explains, the implementation of legislation 'mainly revolves around the question of whether sufficient hospitals, clinics, and doctors willing to perform abortions are available. Institutional factors such as different hospital systems, the possibility to set up private clinics, and the presence of trained personnel are key factors here. Of 
extreme importance are the attitudes of hospitals and clinic boards and personnel'.

The Ministry of Health and Consumption-hereafter called the Ministry of Health-had the responsibility of issuing these regulations. First, the ministry set forth the material and human resources required in clinics for the performance of abortion. ${ }^{10}$ These clinics were required to have a doctor specializing in obstetrics and gynaecology; several nurses and nursing assistants; adequate facilities and tools to perform abortions; a clinical analysis laboratory; a unit for anaesthesia and resuscitation; a blood bank; and a hospitalization unit. Clinics were also required to have a social service unit themselves or to have access to external social services. These requirements were more extensive than what was necessary from a health point of view. The Ministerial Ordinance also established that an assessment committee (comisión de evaluación) composed of five members selected from health personnel must be present during the process leading to each induced abortion. The purpose of these committees was officially to facilitate the implementation of the act and to inform and give advice on problems of implementation.

In August 1985, the Ministry of Health made public a very broad conscience clause. According to this policy, health personnel, without giving concrete reasons, could refuse help in abortion cases pertaining to any of the three grounds. They could express this refusal in writing or by any other means, provided that the refusal was made directly to the head of the clinic, and could refuse to perform either specific abortions or abortions in general.

The WI monitored the implementation of the 1985 abortion act, and, according to Victoria Abril, the technical adviser to the Institute's director, found grave insufficiencies. ${ }^{11}$ In September 1985 the WI drafted the first of a series of internal reports on the problems of the implementation of the 1985 abortion act to be sent to the Ministry of Health. ${ }^{12}$ On 10 July 1986 the WI sent to the Ministry of Health draft legislation on the implementation of the abortion act (Instituto de la Mujer 1986a).

\section{- Dominant frame of the debate}

The debate dealt mainly with the difficulties that appeared when the abortion act was put into practice. In its reports, the WI identified three main problems, among others. First, the assessment committees exercised powers they did not have according to law. It was they, not the doctors, who decided case by case whether abortion should be performed or not. Second, due to the excessive resources requirements, very few public clinics, and no private clinics, were performing abortions. Third, the breadth of the conscience clause meant that very few abortions were actually performed in the very few public hospitals with adequate facilities (Barreiro 1998: 244-6; Instituto de la Mujer 1985; $1986 d, e$ ).

\footnotetext{
* Celia Valiente
} 
In its reports, the WI made recommendations to facilitate access to abortion including, but not limited to, suppressing the assessment committee to simplify the bureaucratic procedures and increasing the number of authorized centres. In 1986 the WI took an even greater step by asking the government to change the statute itself by adding a fourth ground for abortion: the socio-economic circumstances of the pregnant woman (Instituto dela Mujer 1989c:173;1989d.).The Institute's position on abortion and this demand for a more permissive act created serious tensions between the government and the WI. ${ }^{13}$ As a result, the WI put aside its demand for greater liberalization of the law and concentrated its efforts on influencing the regulation of the implementation of the existing act.

\section{* Gendering the debate}

The WI put the abortion debate where, according to feminists, it belonged: at the heart of the discussions on women's rights. The leadership strongly denounced other political and social actors for being overly concerned with other people's rights-for example, those of physicians. An example will illustrate the Institute's role. When the leaders asked the government to further decriminalize abortion, they justified this liberalization in terms of developing the 'fundamental right of the free development of personality [of the woman]', legalizing abortion on demand leaving it 'up to the free decision of the pregnant woman' if this decision was taken in a period during which the viability of the fetus only depends on the woman's will'-that is, when the foetus is not viable outside the woman's body (Instituto de la Mujer 1986e: 7).14

\section{* Policy outcome}

Following in some degree the recommendations of the WI, the Ministry of Health prepared a new draft decree pertaining to the implementation of abortion policy (Ministerio de Sanidad y Consumo 1986b). Subsequently, the WI sent other reports to the Ministry of Health with comments on the ministry's proposals. Eventually the government approved Royal Decree $2,409 / 1986$ of 21 November on the implementation of the 1985 act, which substituted for the previous Ministerial Ordinance of 31 July 1985 (Ministry of Health and Consumption). The new regulations made access to abortion easier by suppressing the assessment committees. It also cutback on the material and human resources required for clinics to have the right to perform low-risk abortions, that is, up to twelve weeks of pregnancy.

\section{- Movement impact}

The negotiation between the Ministry of Health, the Women's Institute, and other policy actors was a process closed to the public. Representatives of 
organizations of the women's movement were not invited to participate in the negotiations. However, before taking state responsibilities in the WI, Carlota Bustelo and most members of the first directorate had for years belonged to women's movement groups. In addition, feminist groups kept up the pressure on the Institute to make further efforts regarding the decriminalization of abortion.

As I have explained elsewhere (Valiente 1995), Spanish feminists did not make a strong unified call for the creation of women's equality institutions in the $1970 \mathrm{~s}$ and early $1980 \mathrm{os}$. A sector of the feminist movement-namely, a part of the radical branch - was clearly against the creation of the WI and constantly accused it of being too moderate regarding some issues. This radical sector chose the issue of abortion to fight against the WI, in order to show that the women's policy machinery meant the deradicalization of the movement. According to these radical feminists, the WI and the socialist government would always promote measures that were far behind what radical feminism wanted, that is, abortion on demand performed in the public health system and free of charge. This radical sector was composed of very few women, but some of them were 'historical feminists', that is, comrades in political battles in the 1970 and early 1980 of of some feminists who later became members of the first WI directive team. A few were active in Madrid, where the headquarters of the WI are located. These radical feminists always criticized WI's motives on abortion, which were considered too moderate for their radical taste. It is hard to measure the impact of radical feminism on the WI, but the impact probably existed. ${ }^{15}$ For all these reasons, I conclude, but with reservations, that representatives of the women's movement participated in the policy process during the second debate.

The policy content of the 1986 Royal Decree, as it was de facto implemented, partly coincided with women's movement goals without fully satisfying them. It is true that most feminist groups mobilized in favour of abortion on demand, which was not provided by the 1986 Royal Decree. Nevertheless, the decree helped to make access to abortion easier. The loose implementation of the Royal Decree in practice made possible the performance of abortion on certain grounds not permitted by Spanish legislation. Therefore, the debate that preceded the second debate studied in this chapter lead to a dual response with respect to the movement impact.

\section{*Women's policy agency activities}

As during the first debate, during the second debate the scope of the WI was very broad. The WI was a bureaucratic part of the state and not a political appointment, and the WI was distant from major power centres. During the second debate, the WI was slightly better organized than during the first debate, since it had more staff and resources. The agency's position coincided with, if not completely fulfilling, women's movement goals in the policy-making process, that

* Celia Valiente 
is, abortion on demand. However, although the WI sought a more permissive abortion act, it concentrated most of its efforts on obtaining final regulations for the existing act which would make access to abortion easier. This choice was probably the most radical option among the feasible alternatives available to the WI, given that, generally speaking, the PSOE refused to allow passage of a more permissive abortion act.

Due to previous experience, Carlota Bustelo and members of the WI directive team were well aware of the importance of intervening in the process of rule-making for such acts of parliament. Let me illustrate this point with the example of the legalization of contraceptives. When the first democratic parliamentary term started in 1977, the selling and advertizing of contraceptives was a crime punishable under the Penal Code. In Parliament, Carlota Bustelo advocated the decriminalization of contraception. Although the reform was eventually approved in 1978, it was not an easy battle. Afterwards, Bustelo and the defenders of the decriminalization of contraception found with dismay that the reform had been very poorly, if at all, implemented. Family planning centres were not set up, and doctors in public hospitals refused to prescribe contraceptives for conscience reasons (Bustelo 1979: 4). Therefore, access to contraception was still very limited, so much so that this issue became another priority of the WI, and a topic to be regularly discussed and negotiated with the Ministry of Health. This experience, along with others, probably made Carlota Bustelo and her team aware of the importance not only of asking for good acts but also of demanding good regulations for the implementation of any act which could enhance women's position. ${ }^{16}$ Thus, the Women's Institute influenced the terms of the debate by bringing the Ministry of Health to accept a gendered definition of the problem of implementation. The WI also included the experiences and points of view of women who had abortions or wanted to have them in the debate (see, for instance, Instituto de la Mujer 1985). Thus the role of the Women's Institute can be classified as insider.

\section{$*$ Women's movement characteristics}

Women's movement characteristics were unchanged from the first debate. The movement was in the stage of consolidation. The movement was not a mass movement-but was not a negligible movement either; it was very close to the left; and it made abortion one of its priorities. The Catholic Church itself acted as a strong opponent of any form of abortion liberalization.

\section{* Policy environment}

The policy sub-system of these health regulations in the bureaucracy was closed. The decision system was organized through regular meetings among 
policy-makers. Participation was limited to a few agents, that is, policy-makers. The Ministry of Health was the principal actor in the debate and controlled the policy space and parameters of the arena. Since its establishment, the Women's Institute had, however, made conscious efforts to build institutional channels of communication with other state units, especially the Ministry of Health. There were periodic meetings between the members of the WI directive team and personnel of the Ministry of Health to discuss a variety of matters including abortion. ${ }^{17}$ Nevertheless, the reader should not infer that the relations between the WI and the Ministry of Health were strong, friendly, and cooperative. Very often the WI directive team got the impression that the Ministry of Health did not welcome WI proposals, or that the ministry politely heard them but did not have any intention of putting them into practice. ${ }^{18}$ Nevertheless, channels of communication existed and were of crucial importance in influencing policymakers in the debate on abortion. Thanks in part to these institution-building efforts, the policy environment around the regulation of the implementation of the 1985 abortion act was open to insider feminist activism.

\section{$\therefore$ CONCLUSION}

This chapter has discovered that state feminism led to a dual response in one of the two policy decisions in the area of abortion in Spain in the mid-1980s. With only a marginal agency during the debate leading to the 1985 abortion act, however, the state pre-empted the movement's demands without accepting women or movement activists into the policy-making process.

The findings of this chapter suggest at least three conditions that are necessary for the WI to successfully gender policy debates and to have policy influence on a specific matter. First, the WI directive team has to show a pronounced interest on the topic. Since the WI is a small institution-the whole staff is slightly more than 150 people-this interest in the issue is in part related to the personal interests of the WI director and members of the WI directive team. As shown, in the mid-1980s abortion was a top priority for the WI.

Second, in order to successfully gender policy debates, the WI has to have created institutional channels of communication with other institutions in the specific policy area. The WI managed to do this regarding abortion. Since its establishment, members of the WI directive team periodically met with personnel of the Ministry of Health to discuss issues including abortion.

Third, obvious as it might be, the knowledge of the WI directive team on specific topics and policy areas is very important. The WI directive team needs to know a lot about specific topics, for instance abortion. But the WI also needs to know the characteristics of the policy areas around concrete issues. Crucial here is the knowledge of the institutional capacity of the state to intervene regarding any given problem, the range of feasible alternatives to solve problems, and the

\footnotetext{
* Celia Valiente
} 
possible difficulties that can be present at the implementation stage of the policy. The empirical case of abortion policies shows that this knowledge existed in the mid-1980s in the WI, and contributed to the successful advancement of feasible demands that were satisfied. In any case, more research is needed on state feminism and political debates in different policy areas, national cases, and chronological periods in order to reach more nuanced conclusions on women's descriptive and substantive representation emanating from women's policy machineries.

As a result of WI's influence, the human and material resource requirements for legal abortion were lowered, and private clinics became interested in becoming authorized centres for performing abortions. Since then, private clinics have performed the overwhelming majority of abortions. In 1998, 53,847 abortions were reported in Spain, a rate of six abortions per 1,000 women of reproductive age. The actual total number of abortions is probably higher. Ninety seven per cent of reported abortions were performed in private centres, and the remaining 3 per cent in public centres. Almost all-97.32 per cent-reported abortions were officially granted because of risks of pregnancy for the physical or mental health of the mother, 2.27 per cent were performed because of presumed deformity of the fetus, 0.03 per cent were performed because of rape, and the remaining 0.38 per cent for unknown reasons (El País 2000: 22). Thanks to the loose implementation of the 1986 Royal Decree, access to abortion is easier than before, and very often goes beyond what is permitted by the $1 \overline{9} 85$ Abortion Act. Most cases officially registered as abortions performed on the ground of the physical and mental health of the mother are in reality performed on socio-economic grounds, which is a type of abortion not permitted by law (Barreiro 1998: 248-52).

There remain serious barriers to abortion. One of them is cost. Private clinics charge fees while public centres do not. Since most abortions take place in more costly private centres, some women cannot afford an abortion. A second barrier is the scarcity of authorized clinics in some cities, towns or regions; abortion rates vary widely among different regions (El País 2000: 22). Third, because many abortions are performed for reasons not permitted by law, doctors and women are under continuous threat of prosecution. Only a reform in the 1985 abortion act can remedy this situation (Barreiro 1998: 248-52). 


\section{* Notes}

1 A seminal Ph.D. dissertation written in Spanish, 'Democracy and Moral Conflict: The Politics of Abortion in Italy and Spain' (Barreiro 1998), has been of immense value for the writing of these empirical case studies. I follow this dissertation very closely when I describe the two abortion debates in this chapter. The sources for this chapter also include published and unpublished documents from the Women's Institute, a parliamentary debate, legislation, unpublished documents from the Ministry of Health and Consumption, and press files.

2. This part of the debate in the Congress of Deputies can be consulted in DSCD $(1983 a, b, c, d ; 1985 d)$.

3 This part of the debate in the Senate can be consulted in DSS (1983: 1852-1906).

4 The representation of women who have abortions as people under stress and in need of help is common in policy statements issued in other Western countries (Outshoorn 1996a).

5 The debate in the Congress of Deputies can be consulted in DSCD $(1985 a ; 1985 b)$. The debate in the Senate can be consulted in DSS (1985:5994-6030).

6 See, for instance, interventions of: deputy Bandrés Molet from the Mixed Parliamentary Group (DSCD 1983a: 1870); (female) deputy Pelayo Duque from the Socialist Parliamentary Group (DSCD 1983c: 2927); and deputy Pérez Royo from the Mixed Parliamentary Group (DSCD 1983c: 2938).

7 In 1996, the Ministry of Labour and Social Security and the Ministry of Social Affairs were merged into the Ministry of Labour and Social Affairs.

8 Many sources document this priority status. For instance, most issues of the WI periodical journal Mujeres (Women), published in Madrid, contain pages on the topic. According to the Women's Institute, Mujeres had a circulation of 8,000 copies in 1983 and of 20,00o copies in 1986. Pages on abortion can be consulted in Mujeres (1983: 6, 9-11; 1984a: 32-33, b: 15-17, 27, 32, 49, $c: 72$ ). For more information on the women's institute, see Threlfall $(1996 ; 1998)$ and Valiente $(1995 ; 1997)$.

9 For accounts of the Spanish feminist movement, see: Durán and Gallego (1986); Escario, Alberdi, and López-Accotto (1996); Folguera (1988); Kaplan (1992); Scanlon (1990); Threlfall $(1985,1996)$.

10 Ministerial Ordinance of 31 July 1985, Ministry of Health and Consumption.

11 Personal interview, Madrid, 14 August 1998.

12 The series comprises: Instituto de la Mujer $(1985,1986 a, b, c, d, e, f, g)$.

13 This information was provided by WI director Carlota Bustelo in a personal interview conducted by the author in Madrid on 6 April 1994 (Valiente 1995).

14 Author's translation.

15 This description of radical feminism in Spain and its position and tactics regarding abortion and the WI is drawn from a personal interview the author conducted with Justa Montero on 25 May 1994 from the Pro-Abortion Commission (Valiente 1995).

16 Carlota Bustelo's understanding of the significance of the implementation of acts is contained in some of her writings (Bustelo $1986: 275 ; 1987: 15 ; 1988: 281-2$ ).

* Celia valiente 
17 Published WI documents mentioned these meetings as early as in 1984: for instance, Mujeres (1984a: 32-33).

18 This description of the relationships between the WI and the Ministry of Health is drawn from the interviews conducted with Victoria Abril in Madrid, 14 August 1998, and Carlota Bustelo in Madrid, 6 April 1994 (Valiente 1995). 